\title{
Effects of microorganisms on quality and some indices of semens of male patients with infertility in kano metropolis, Nigeria
}

\begin{abstract}
Infertility is the inability of a sexually active, non-contraception couple to achieve spontaneous pregnancy in one year. About $15 \%$ of couples do not achieve pregnancy within one year and seek medical treatment for infertility.
\end{abstract}

Volume 4 Issue 5 - 2018

\author{
Nasir S Abubakar,' Abdulsamad Muhammad \\ $\mathrm{A},{ }^{2}$ Muhammad $\mathrm{Ali}^{3}$ \\ 'Department of Medical Laboratory Science, Bayero University \\ Kano, Nigeria \\ ${ }^{2}$ Department of Animal Health, Bayero University Kano, Nigeria \\ ${ }^{3}$ Department of Biological Sciences, Federal University Gusau, \\ Nigeria
}

Correspondence: Muhammad Ali, Department of Biological Sciences, Federal University Gusau, Nigeria, Email alimuhd4real@gmail.com

Received: July 31, 2018 | Published: September 19, 2018

\section{Introduction}

Infertility is the inability of a sexually active, non-contraception couple to achieve spontaneous pregnancy in one year. About $15 \%$ of couples do not achieve pregnancy within one year and seek medical treatment for infertility. ${ }^{1}$ One in eight couples encounters problems in attempting to conceive a first child and one in six when attempting to conceive a subsequent child.

Both sexes are more or less equally involved in infertility problem. ${ }^{2}$ Men either alone or along with their female partners, contribute to $40-45 \%$ cases of infertility. ${ }^{3}$ Furthermore, infectious etiology involving bacteria, virus, fungi, and protozoa contribute to $15 \%$ of male factor infertility. ${ }^{4,5}$ Some of the microbes are acquired exogenously or endogenously and they could cause infertility in several ways: by damaging sperm motility, deterioration of spermatogenesis, altering the chemical composition of the seminal fluid by dysfunction of accessory sex glands, or by inducing autoimmune processes due to inflammation. ${ }^{6}$ Normal semen is composed of the fluids from the vas deferens, the seminal vesicles, the prostate gland and the mucous glands, especially the bulbourethral glands. The major bulk of the semen is seminal vesicle fluid (about $60 \%$ ), which is the last to be ejaculated and serves to wash the sperm out of the ejaculatory duct and urethra. ${ }^{7}$

Normal spermatozoa measure $50-70 \mu \mathrm{m}$ in length. Each consists of an oval shaped head (with acrosomal cap), which measures $3-5 \times 2-$ $3 \mu \mathrm{m}$, a short middle piece and a long thin tail (at least $45 \mu \mathrm{m}$ in length). At least $50 \%$ of spermatozoa should show normal morphology in normal semen. ${ }^{8}$ The $\mathrm{WHO}^{1}$ minimal criteria for normal semen include on the average a volume of $1.5 \mathrm{ml}$, minimal count of 20 millions sperms/ $\mathrm{ml}$, sperm motility of $60 \%$ and no blood cells. The volume of semen and the sperm count decrease rapidly with repeated ejaculation. Even though, it takes only one sperm to fertilize the ovum, each milliliters of semen normally contains about 100 million sperms. In the semen analysis, concentration, motility and morphology measured traditionally with manual methods are still the most important parameters in the initial investigation of the male factor infertility. ${ }^{9}$

The most frequently used techniques are count chambers (e.g. haemocytometer and Makler chamber) to measure concentration, and wet preparation to measure motility. ${ }^{10}$ Furthermore, the sperm quality analyser (SQA) performs an indirect analysis of sperm movement. ${ }^{11}$ The SQA has a photoelectric cell that detects the optic density fluctuations caused by the motility of spermatozoa. The analogue signal registered is converted digitally to provide the sperm motility index (SMI) value, ${ }^{11}$ which is affected by the number of spermatozoa and by the type of motility. ${ }^{12}$ The study was aimed to evaluate the effects of microorganisms on quality and some indices of semen of male patients with infertility attending Murtala Muhammad Specialist Hospital (MMSH) in Kano metropolis, Nigeria.

\section{Materials and methods}

\section{Study area}

The study was conducted at microbiology department of Murtala Muhammad Specialist hospital (MMSH), Kano. Kano state is located in the North-west Nigeria with coordinates $11^{0} 30 \mathrm{~N} 8^{0} 30 \mathrm{E}$. It shares borders with Kaduna state to the south- west, Bauchi state to the South-East, Jigawa state to the East, Katsina state to the West and Niger republic to the North. It has a total area of $20,131 \mathrm{~km}^{2}(7,777 \mathrm{sqm})$ and population of $11,058,300 .^{13}$

\section{Study population}

A total of 200 samples were collected from male patients who had either primary or secondary infertility cases. 


\section{Inclusion criteria for patients}

Male patients with any kind of infertility attending MMSH were involved in the study.

\section{Exclusion criteria}

Male patients who refused to observed at least three days of sexual abstinence prior to the test.

Patients who refused to suspend any chemo antibiotic treatment for at least one week prior to sample collection.

\section{Ethical clearance}

An approval for the study (with reference number: MOH/Off/797/ T.I/49) was obtained from research and ethic committee Kano state ministry of health. The aim of the study was explained clearly to the clients and informed consent obtained before proceeding to the study.

\section{Determination of sample size}

Sample size for the study was determined from a standard formula for the calculation of minimum sample size.${ }^{14}$ Sample size was given by the formula

$$
\begin{aligned}
& \mathrm{N}=\left(\mathrm{Z}_{1}-\mathrm{a}\right)^{2}(\mathrm{p})(1-\mathrm{p}) / \mathrm{d}^{2} \\
& \mathrm{~N}=\text { minimum sample size }
\end{aligned}
$$

$\mathrm{Z}_{1-. \mathrm{a}} \mathrm{a}$ value of standard normal deviate which at $95 \%$ confidence interval has found to be 1.96 .

$\mathrm{P}=$ the best estimate of prevalence obtained from literature review $(12.3 \%)$ and

$\mathrm{d}=$ difference between the true population rate and sample that can be tolerated, this is the absolute precision (in percentage) on either side of the population. $\mathrm{N}=(1.96) 2(0.123)(1-0.123) /(0.05)^{2}=165.758$ as the minimum number of samples for the study. Therefore, a total of 165.759 with $20 \%$ (33.152) of this subject will be added to the research for attrition, making a total of approximately 200 samples.

\section{Sample collection}

Semen specimens were collected from males with infertility attending the clinic and General out-patients department (GOPD) of MMSH Kano. The samples were collected from patients who have had 3-7 days of sexual abstinence from intercourse preferably by masturbation into a sterile clean wide-mouth container. Upon collection, samples were transferred without any delay to the Microbiology department of MMSH in a nearly as possible to body temperature by placing the container inside a flask containing water at $33-37^{\circ} \mathrm{C}$. Time of collection to the time the samples were received in the laboratory was recorded which must not exceed 45 minutes. Furthermore, analyses of samples with SQA machine were conducted at Microbiology department, Aminu Kano teaching hospital (AKTH), Kano.

\section{Macroscopic examination}

Appearance: Semen samples were examined immediately after liquefaction or within one hour of ejaculation.

Volume: The volumes of the seminal fluid were measured by decanting the whole sample aseptically into a graduated centrifuge tube and the level were recorded in $\mathrm{ml} \pm 0.1{ }^{1}$

pH: The $\mathrm{pH}$ of the samples was determined by using $\mathrm{PH}$ meter which were read by immersing the electrode into the sample. ${ }^{15}$
Liquefaction: The liquefaction of semen samples was determined by allowing samples to stand at room temperature for 15 minutes but no longer 60 minute after ejaculation. ${ }^{1}$

Viscosity: The viscosity of the samples was determined with the aid of Pasteur pipette. A drop of semen was allowed to fall back to the sample and the length of the thread was observed. A normal sample leaves the pipette as small discrete drops while in abnormal cases, the drop forms a thread greater than $2 \mathrm{~cm}$ long. ${ }^{15}$

\section{Microscopic examination}

A wet preparation technique was carried out on each sample for the presence of cells other than spermatozoa such as leucocytes, red blood cells and yeast cells. ${ }^{15}$ On to a clean grease free slide, a drop of well mixed and liquefied sample was drop and cover with cover slide. It was then observed microscopically using $\mathrm{x} 40$ objective lens for the presence of cells other than sperm cells.

\section{Analysis (SQA IIC P)}

After liquefaction for 60 minutes, the semen samples were processed for conventional WHO parameters and other parameters. ${ }^{16}$ The SQA II capillary was filled with collected semen sample. The rubber cap of the testing capillary was firmly squeezed and the testing capillary was dipped into well mixed and liquefied semen well below the surface of the sample. The pressure on the rubber cap was released to fill the capillary with semen. The capillary was checked to see if there is sample above the T or wide part of the capillary. The tip of the capillary was briskly wiped with soft and non hairy tissue paper. The capillary was inserted with the arrow side up into the SQA II. ${ }^{16}$ The test bottom was pressed, and after 45-second test period the SQA digitally displayed the fallowing parameter: Total sperm concentration, $\%$ progressive motility, \% Normal morphologies, Functional sperm concentration in million per milliliter, Motile sperm concentration in million per milliliter, Sperm motility index and Total sperm count in sample in million.

\section{Culture}

Culture of seminal fluid samples was done in aseptic condition within one hour of collection in accordance with WHO. ${ }^{1}$ The seminal fluids were diluted with sterile saline (1:10) and centrifuged at1500RPM for $15 \mathrm{~min}$. After removing the supernatant, the sediments were cultured using $10 \mu 1$ calibrated loops on Nutrient agar, Blood agar, Chocolate agar and Mac Conkey agar which were incubated aerobically and in $5 \% \mathrm{CO}$ at $37^{\circ} \mathrm{C}$ for 24 hours for the isolation of pathogenic microorganism. Seminoculture were considered positive when the number of colonies was $\geq 104 \mathrm{CFU} / \mathrm{ml}$ for Gram positive cocci and $\geq 105 \mathrm{CFU} / \mathrm{ml}$ for Gram negative. ${ }^{17}$ Sabouraud dextrose agar slants were used for the isolation of yeasts and yeast-like fungi after 48 hours aerobic incubation at $37^{\circ} \mathrm{C}$. Mycoplasmal agar enriched with $30 \%$ serum and supplemented with $100 \mu \mathrm{g} / \mathrm{ml}$ ceftazidime was used for the isolation of Mycoplasma species which were declared negative at 96 hours incubation at $37^{\circ} \mathrm{C} .{ }^{17}$

\section{Isolation and identification of isolates}

Nutrient agar plates were prepared for the isolation of pure colonies from the primary plates. A colony was picked and streaked on nutrient agar plates and then incubated at $37^{\circ} \mathrm{C}$ for 24 hours. Using a sterile wire loop, a colony from each plate was picked and prepare for Gram's staining and other biochemical tests, some of which include Catalase, Coagulase, DNAse, Triple iron agar, Oxidase and API 20E Test. ${ }^{17}$ 


\section{Results}

Table 1 shows the comparison of abnormal semen parameters among samples with good, medium and poor counts. The result shows there was statistically no significant association $(\mathrm{p}>0.05)$ between sperm concentration and abnormal sperm parameters (motility $<30 \%$ and morphology $<20 \%)$. The result indicated the majority $(63 / 83)$ of individuals with sperm motility of $<30 \%$ presented poor sperm count $\left(0-20 \times 10^{6} / \mathrm{ml}\right)$. Similarly, majority $(66 / 84)$ of individuals with sperm morphology of $<20 \%$ recorded poor sperm count. A small fraction $(3 / 83)$ of individuals with sperm motility of $<30 \%$ had good sperm count $\left(60 \times 10^{6} / \mathrm{ml}\right)$. Also a small fraction $(2 / 84)$ of individuals with sperm motility of $<20 \%$ recorded good sperm count $\left(>60 \times 10^{6} / \mathrm{ml}\right)$. The distribution of semen parameters among various microorganisms are shown in Table 2. The highest number of isolated microorganisms was observed in samples with concentration of $0-20 \times 10^{6} / \mathrm{ml}$. This was followed by those with concentration of $20-60 \times 10^{6} / \mathrm{ml}$ while the least number of microorganisms was observed from samples with concentration $>60 \times 10^{6} / \mathrm{ml}$. The table also shows the highest progressive motility been recorded in a few fraction of Bacteriospermic samples while majority shows poor to medium motility. Motility rate was reduced significantly in samples with pathogenic microorganisms.

Table I Comparison of abnormal semen parameters among individuals with, Good Medium and Poor sperm count

\begin{tabular}{lllll} 
Parameter & $\begin{array}{l}\text { Medium } \\
(20-60 \times \\
\left.10^{6} / \mathrm{ml}\right)\end{array}$ & & $\begin{array}{l}\text { Poor } \\
\left(\mathbf{0}-20 \times 10^{6} / \mathrm{ml}\right)\end{array}$ & P-value \\
\hline $\begin{array}{l}\text { Motility }(<30 \%) \\
\begin{array}{l}\text { Morphology } \\
(<20 \%)\end{array}\end{array}$ & 3 & 17 & 63 & 0.854 \\
\hline
\end{tabular}

Key: $<$ Less than, $>$ Greater than, *statistically not-significant at $p>0.05$

Table 2 Distribution of semen parameters in relation to microbial isolates

\begin{tabular}{|c|c|c|c|c|c|c|c|c|c|}
\hline \multirow[t]{2}{*}{ Bacteria } & \multicolumn{2}{|c|}{ Conc. $\left(10^{6} / \mathrm{ml}\right)$} & \multicolumn{3}{|c|}{ Motility (\%) } & \multicolumn{2}{|c|}{ Morphology (\%) } & \multirow[b]{2}{*}{ Medium } & \multirow[b]{2}{*}{ Poor } \\
\hline & Good & Medium & Poor & & Medium & Poor & & & \\
\hline & $>60$ & $20-60$ & $0-20$ & Good $>50$ & $30-50$ & $0-30$ & Good $>30$ & $20-30$ & $0-20$ \\
\hline S. aureus & 3 & 12 & 16 & 4 & 8 & 19 & 6 & 5 & 20 \\
\hline CN S.sp & 4 & 2 & 8 & 4 & 5 & 5 & I & 5 & 8 \\
\hline E. coli & 2 & 3 & 6 & I & 3 & 7 & 0 & 4 & 7 \\
\hline P. mirabilis & 0 & 2 & 3 & I & 2 & 2 & 2 & I & 2 \\
\hline Klebsiella & I & 3 & 2 & 0 & 2 & 4 & 2 & 2 & 2 \\
\hline P. aeruginosa & 0 & 0 & 3 & I & I & 1 & 0 & 0 & 3 \\
\hline Mycoplasma & 0 & 0 & 1 & 0 & 0 & 1 & 0 & I & 0 \\
\hline Neisseria & 0 & 1 & I & 0 & 2 & I & 0 & I & I \\
\hline
\end{tabular}

Key: CN S. sp = Coagulase negative Staphylococcus specie

Distribution of Bacteriospermic and non-bacteriospermic samples with respect to World Health Organization (WHO) parameters are shown in Table 3. The results showed there was significant difference $(\mathrm{p}<0.05)$ between bacteriospermia and non-bacteriospermia. Sperm concentration among Bacteriospermic samples (76/200) was low with only 16 having good sperm count $\left(>60 \times 10^{6} / \mathrm{ml}\right), 19$ showed medium count $\left(20-60 \times 10^{6} / \mathrm{ml}\right)$ while 41 revealed poor count $\left(0-20 \times 10^{6} / \mathrm{ml}\right)$. Similarly, sperm motility was observed to be low in bacteriospermia (76/200) compare to non-bacteriospermia (124/200). Only a small fraction (13/76) of Bacteriospermic samples showed good ( $>60 \times 10^{6 /} /$ $\mathrm{ml}$ ) morphologies with the remaining 19and 14 showed medium (30$\left.50 \times 10^{6} / \mathrm{ml}\right)$ and poor $\left(0-20 \times 10^{6} / \mathrm{ml}\right)$, respectively. Table 4 shows distribution of Bacteriospermic and non-bacteriospermic samples with respect to "other" parameters. The results showed there was significant difference $(\mathrm{p}<0.05)$ between Bacteriospermia and non-bacteriospermia. Out of $76(38 \%)$ bacteriospermic samples tested, $21(10.5 \%)$ indicated well $\left(>13 \times 10^{6} / \mathrm{ml}\right)$ functional sperm count (FSC) with 16 $(8 \%)$ and 39 (19.5) indicating medium and poor FSC, respectively. Moreover, of the 76 bacteriospermic samples tested 19 (25\%) showed good $\left(26 \times 10^{6} / \mathrm{ml}\right)$ motile sperm concentration (MSC) while the remaining $17(22.4 \%)$ and $40(52.6 \%)$ showed medium (12-26 x 10\% $\mathrm{ml})$ and poor $\left(0-10 \times 10^{6} / \mathrm{ml}\right) \mathrm{MSC}$, respectively. Similarly, out of 76 bacteriospermic samples tested, $18(23.7 \%)$ showed good $\left(>160 \times 10^{6} /\right.$ $\mathrm{ml})$ sperm motility index (SMI) while they showed medium (80-160 x $\left.10^{6} / \mathrm{ml}\right)$ and poor $\left(0-10 \times 10^{6} / \mathrm{ml}\right) \mathrm{SMI}$, respectively

Table 3 Distribution of Bacteriospermia and non-bacteriospermia among individuals with respect to conventional parameters

\begin{tabular}{|c|c|c|c|c|}
\hline Parameter & Bacteriospermia & $\begin{array}{l}\text { Non- } \\
\text { bacteriospermia }\end{array}$ & $X^{2}$-value & p-value \\
\hline \multicolumn{5}{|c|}{ Concentration $\left(\times 10^{6} / \mathrm{ml}\right)$} \\
\hline Good (> 60) & 16 & 62 & & \\
\hline Medium (20-60) & 19 & 26 & 19.221 & 0.000 \\
\hline Poor $(0-20)$ & 41 & 34 & & \\
\hline \multicolumn{5}{|l|}{ Motility (\%) } \\
\hline Good $(>50)$ & 13 & 57 & & \\
\hline
\end{tabular}


Table continued...

\begin{tabular}{lllll}
\hline Parameter & Bacteriospermia & $\begin{array}{l}\text { Non- } \\
\text { bacteriospermia }\end{array}$ & $\mathbf{X}^{2}$-value & p-value \\
\hline Medium (30-50) & 17 & 49 & 36.116 & 0.000 \\
Poor (0-30) & 46 & 18 & & \\
Morphology (\%) & & & & \\
Good (>30) & 10 & 62 & 36.116 & 0.000 \\
Medium (20-30) & 21 & 35 & & \\
Poor (0-20) & 45 & 27 & & \\
\hline
\end{tabular}

*Statistically significant at $\mathrm{p}<0.05$, *Plus 33 azoospermia

Table 4 Distribution of Bacteriospermia and non-bacteriospermia among individuals with respect to other semen parameters

\begin{tabular}{|c|c|c|c|c|}
\hline Other Parameter & Bacteriospermia & Non-bacteriospermia & $X^{2}$-value & P-value \\
\hline \multicolumn{5}{|l|}{ FSC $\left(x 10^{6} / \mathrm{ml}\right)$} \\
\hline Good (>13) & 21 & 51 & & \\
\hline Medium (3-13) & 16 & 22 & 24.128 & 0.000 \\
\hline Poor (0-3) & 39 & 18 & & \\
\hline \multicolumn{5}{|l|}{ MSC $\left(\times 10^{6} / \mathrm{ml}\right)$} \\
\hline Good (>26) & 20 & 47 & & \\
\hline Medium (10-260 & 17 & 20 & 9.383 & 0.000 \\
\hline Poor $(0-10)$ & 39 & 24 & & \\
\hline \multicolumn{5}{|l|}{ SMI } \\
\hline Good (>160) & 18 & 39 & & \\
\hline Medium (80-160) & 15 & 22 & 7.653 & 0.000 \\
\hline Poor $(<80)$ & 43 & 30 & & \\
\hline
\end{tabular}

Key: FSC-Functional sperm count, MSC-Motile sperm concentration, SMI-Sperm motility index, *statistically significant at p<0.05, *plus 33 azoospermic samples.

\section{Discussion}

The comparison of abnormal semen parameters among samples with good, medium and poor counts was shown in Table 1 . The result shows there was statistically no significant association $(\mathrm{p}>0.05)$ between sperm concentration and abnormal sperm parameters (motility $<30 \%$ and morphology $<20 \%$ ). The result indicated the majority $(63 / 83)$ of individuals with sperm motility of $<30 \%$ presented poor sperm count $\left(0-20 \times 10^{6} / \mathrm{ml}\right)$. Similarly, majority $(66 / 84)$ of individuals with sperm morphology of $<20 \%$ recorded poor sperm count. A small fraction $(3 / 83)$ of individuals with sperm motility of $<30 \%$ had good sperm count $\left(60 \times 10^{6} / \mathrm{ml}\right)$. Also a small fraction $(2 / 84)$ of individuals with sperm motility of $<20 \%$ recorded good sperm count $\left(>60 \times 10^{6}\right)$ $\mathrm{ml})$. The interrelationships of microorganism and semen parameters are shown in Table 2. The highest number of isolated microorganisms was observed in samples with concentration of $0-20 \times 10^{6} / \mathrm{ml}$. This was followed by those with concentration of $20-60 \times 10^{6} / \mathrm{ml}$ while the least number of microorganisms was observed from samples with concentration $>60 \times 10^{6} / \mathrm{ml}$. The table also shows the highest progressive motility been recorded in samples without pathogenic microorganisms. Motility rate was reduced significantly in samples with pathogenic microorganisms. This implies that the presence of pathogenic microorganisms exerts a negative effect on spermatozoa concentrations which supports earlier observations. ${ }^{18,19} S$. aureus occur in all ranges to spermatozoa concentrations. This may be related to its success as major human commensal and pathogen, partly due to some strain that have the ability to rapidly develop resistance to several antimicrobial agents. ${ }^{20}$ This suggests that these microorganisms are strongly associated with deterioration of semen indices. Similarly, the presence of pathogenic microorganisms in seminal fluid as recorded in this study was associated with decline in total and progressive motility indices when compared with non-pathogenic microorganisms which agrees with Golshani et al. ${ }^{21}$ This is suggestive that pathogenic microorganisms markedly affect the kinetic of characteristics of spermatozoa when present in semen. ${ }^{22}$ For instance, E. coli, Coagulase Negative Staphylococci may play an important role in sperm impairment due to infertility, worldwide. ${ }^{21}$ Their significant negative effect is towards sperm motility, morphology and vitality. ${ }^{23}$ Ekhaise \& Richard ${ }^{24}$ quoted Stephen et al. (1989) who equally reported that, the viability and structural integrity of the semen lies on its characteristic feature of mobility. It is therefore probable that the presence of $E$. coli in semen decreases sperm motility which is dependent upon sperm bacterial $/$ semen $\mathrm{ratio} / \mathrm{ml}$.

Distribution of bacteriospermic and non-bacteriospermic samples with respect to WHO parameters were shown in Table 3 . The results showed there was significant difference $(\mathrm{p}<0.05)$ between bacteriospermia and Non-bacteriospermia. Sperm concentration among Bacteriospermic samples (76/200) was low with only 16 having good sperm count $\left(>60 \times 10^{6} / \mathrm{ml}\right), 19$ showed medium count $\left(20-60 \times 10^{6} / \mathrm{ml}\right)$ while 41 revealed poor count $\left(0-20 \times 10^{6} / \mathrm{ml}\right)$. Similarly, sperm motility was observed to be low in bacteriospermia $(76 / 200)$ compare to Non-bacteriospermia (124/200). Only a small fraction (13/76) of Bacteriospermic samples showed good $\left(>60 \times 10^{6 /} / \mathrm{ml}\right)$ morphologies with the remaining 19 and 14 showed medium $\left(30-50 \times 10^{6} / \mathrm{ml}\right)$ and poor $\left(0-20 \times 10^{6} / \mathrm{ml}\right)$, respectively.

Table 4 shows distribution of bacteriospermic and non bacteriospermic samples with respect to "other" parameters. The results 
showed there was significant difference $(\mathrm{p}<0.05)$ between Bacteriospermia and Non-bacteriospermia. Out of $76(38 \%)$ bacteriospermic samples tested, $21(10.5 \%)$ indicated well $\left(>13 \times 10^{6} / \mathrm{ml}\right)$ functional sperm count (FSC) with 16 (8\%) and 39 (19.5) indicating medium and poor FSC, respectively. Moreover, of the 76 bacteriospermic samples tested $19(25 \%)$ showed good $\left(26 \times 10^{6} / \mathrm{ml}\right)$ motile sperm concentration (MSC) while the remaining $17(22.4 \%)$ and $40(52.6 \%)$ showed medium $\left(12-26 \times 10^{6} / \mathrm{ml}\right)$ and poor $\left(0-10 \times 10^{6} / \mathrm{ml}\right)$ MSC respectively. Similarly, out of 76 bacteriospermic samples tested, 18 (23.7\%) showed good $\left(>160 \times 10^{6} / \mathrm{ml}\right)$ sperm motility index (SMI) while 15 and 43 showed medium $\left(80-160 \times 10^{6} / \mathrm{ml}\right)$ and poor $\left(0-10 \times 10^{6} / \mathrm{ml}\right)$ SMI, respectively.

\section{Conclusion}

The present study revealed that occurrence of microorganisms in semen had significantly lower $(\mathrm{p}<0.005)$ spermatozoa concentrations and motility parameters. In the study Staphylococcus aureus is the most prevalent microbes associated with infertility in male partners of infertile couples and the presence of Escherichia coli might be an indication of poor personal hygiene among couples.

\section{Acknowledgements}

The authors wish to acknowledge to the technical staff Microbiology laboratory of Murtala Muhammad Specialist Hospital Kano and those of Aminu Kano Teaching Hospital Kano for sample provision and use of laboratory facilities. Thanks to Kano State Government for granting us with ethical clearance.

\section{Conflict of interest}

The author declares no conflict of interest.

\section{References}

1. World Health Organization (WHO).Manual for the Standardized Investigation and Diagnosis of the Infertile Couple. Cambridge University Press: Cambridge; 2010.

2. Deka PK, Sarma S. Psychological aspects of infertility. British Journal of Medical Practitioners. 2010;3(3):a336.

3. Weng SI, Chiu M, In MF, et al. Bacterial communities in semen from men of infertile couples: metagenomic sequencing reveals relationships of seminal microbiota to semen quality. PLoS ONE. 2014;9(10):e110152.

4. Diemer T, Huwe P, Ludwig M, et al. Urogenital infection and sperm motility. Andrologia. 2003;35(5):283-287.

5. Keck C, Gerber Schafer C, Clad A, et al. Seminal tract infections: impact on male fertility and treatment options. Hum Reprod Update. 1998;4(6):891-903.

6. Ibadin O, Iben IN. Bacteriospermia and sperm quality in infertile male patient at University of Benin Teaching Hospital, Benin City, Nigeria. Mal J Microbiol. 2008;4(2):65-67.
7. Guyton AC. Human Physiology and Mechanisms of Diseases. $5^{\text {th }}$ end. W.B. Saunders Publishers, 1992. p. 690.

8. Guzick S, Overstreet JW, Factor Litrak P. Sperm Morphology, Motility and Concentration in Fer-tile and Infertile Men. $N$ Engl J Me. 2001;345(19):1388-1393.

9. Yeung $\mathrm{CH}$, Cooper TG, Nieschlag E. A technique for standardization and quality control of subjective sperm motility assessments in semen analysis. Fertil Steril. 1997;67:1156-1158.

10. Neuwinger J, Behre H, Nieschlag E. External quality control in the andrology laboratory: an experimental multicenter trial. Fertil Steril. 1990;54:308-314.

11. Bartoov B, Ben Barak J, Mayevsky A. Sperm motility index: a new parameter for human sperm evaluation. Fertil Steril. 1991; 56(1):108-112.

12. Metzker ML. Sequencing technologies-the next generation. Nat Rev Genet. 2010;11(1):31-46.

13. Encylopedia. The history and Geography of Kano, 2017.

14. Singha S, Satoh KS, Orikasa I, et al. Studies on pyospermia in male infertility. Nihon Hinyokika Gakkai Zasshi. 1990;81(2):170-177.

15. Ochsendorf FR. Sexually transmitted infections: impact on male fertility. Andrologia. 2008;40(2):72-75.

16. SQA User Guide Manual. Advanced Fifth Generation sperm Quality analyser (SQA II-P), 2010.

17. Chessbrough M. District laboratory practice in tropical countries, 2 nd edn, part 2. England, Cambridge university press; 2006. p. 440.

18. Glover TD, Barrett CL, Tyler HG. Human Male Fertility and Semen Analysis. Academic Press: London; 1990. p. 247.

19. Onemu SO, Ibeh IN. Studies on the significance of positive bacterial semen cultures in male fertility in Nigeria. Int J Fertil Womens Med. 2001;46(4):210-214.

20. Butt F, Akram N. Semen analysis parameters: experiences and insight into male infertility at a tertiary care hospital in Punjab. J Pak Med Assoc. 2013;63(5):558-562.

21. Gulshani I, Taylor CE, Ross MD. Effect Methotrexate on subsequent fertility in patients undergoing ART. Fertility and Sterility. 2006;92(2):515-51.

22. Onemu SO, Ogbin AO, Oplon EA. Microbiology and Semen indices of sexually active Males in Benin City, Edo State Nigeria. Journal of Bacteriology research. 2010;2(5):55-59.

23. Rodin DM, Larone D Goldstein M. Relationship between semen cultures, leukospermia, and semen analysis in men undergoing Fertility evaluation. Fertil Steril. 2003;3:1555-1558.

24. Ekhaise FO, Richard FR. Common bacterial isolates associated with semen of men attending the fertility clinic of the University of Teaching Hospital (U.B.T.H), Benin City, Nigeria. Afr J Microbial Res. 2011;5(22):3805-3809. 